\title{
CERVANTINE DISCRETION IN RAMÓN DE LA CRUZ
}

Gregorio C. Martin

The Cervantine concept of discretion being a middle measurement equidistant from two extremes and a means by which man can recognize the differences between good and evil is perfectly displayed, I believe, in the one-act farce of Ramón de la Cruz, $L a$ presumida burlada. Following another literary theory of Cervantes, this short work both delights and teaches at the same time. Between jests and reality, the author presents human problems with great subtlety.

The snob is Doña María, a country girl who has changed from servant to mistress of the house by virtue of her marriage to don Gil. This sudden change of fortune has made her very conceited, to the point that she treats both her husband and her former companions among the housekeeping staff arrogantly. Her parents, simple country people, come to visit her. María, who after her marriage pretended to come from a well-to-do family, refuses to see them so that her new society friends will not learn the truth of her background. This deceit is prevented by the intervention of her husband who wishes to awaken her to the extreme limit of her vanity.

The author of a brief farce (as is the Spanish sainete), like the author of a short story, is limited by the duration of his work and has to undertake the main theme without delay. This is what Ramón de la Cruz dces, presenting immediately to us the conflict of a matrimonial problem which the husband confides to his friend. What is the origin of this conflict? Two things - arrogance and vanity. His wife, upon finding herself elevated from servant to served, has become "prouder than a peacock" and very vain. María destroys the peace that previously existed in the house because she trys to change things in such a way that it unbalances the social order in which she lives. Arrogance and vanity have the upper hand and now there is no peace, no harmony. As one servant says, speaking of the time when María was also a servant: "Let us be quiet and remember the time when we lived like brothers, with an enviable peace."

Exactly what happened that would cause María to become so vain and haughty? She was a plain country peasant, as is Sancho in Don Quijote. Like Sancho, she left her roots and went out into the world, the great world of the city. There María discovered that the important thing is not what you are, but what you seem to be. Men appear to be honorable gentlemen and they are rogues; they seem rich, but they are poor. As in Don Quijote, these are the enchanters of real life. They cover themselves with the mask of appearances until it is imposible to distinguish the real from the false. We find thus a 
parallel between María and Sancho, who in the first part of Don Quijote is the spectator of enchantments and deceits; but in the second part, with experience as his teacher, he changes a peasant into a beautiful damsel. In the first part of her life María was a spectator, but following her marriage she, like an enchanter, transforms herself from servant to a great lady. María succeeds in her mascarade. Everyone believes her because in this world of hipocrisy and falsehood, since everyone is an enchanter of one kind or another, illusion is accepted as the norm of life. As someone points out at the end of the play, everyone would be ashamed if the truth were known.

These enchanters and their fabricated world are described to us through the eyes of María's family, honest peasants who represent what is natural and spontaneous. Their descriptions of the citizens they encounter $c n$ their visit to Madrid are revealing, but at the same time comical because comedy is one of the goals of the sainete. Since the comic is also an object of satire, Ramón de la Cruz is indeed satirizing a society that is in need of ethics because it lacks the type of education in which ethics would be included. It is the same type of society and education that Torres Villarroel describes for us in his Vida and Francisco de Isla in Fray Gerundio. This is what the Spaniards of the Enlightenment attempted to change under Carlos III - an education based upon learning a series of principles without any practical application, under the direction of an ignorant and incompetent teacher. This is represented in the sainete by Maria's music teacher. He is another enchanter; he knows all the tricks needed to shine in society. Ha has heard of the Aristotelian principle that Cervantes repeats in Don Quijote; namely, that all works of art should have a beginning, a middle and an end. Unfortunately, María's teacher has understood complementely the reverse and is totally inept as a teacher; he is a pedant.

What does the society of enchanter and pedants need? Men of discretion are needed to teach the truth and to uncover the false. This is what Maria's husband does. He is a clear-thinking man, who always expresses himself with moderation and restraint. He realizes that his marriage is troubled, but - in a very atypical Spanish attitude - instead of being dominated by his Latin temperment, he seeks a means of demonstrating to his wife the misconception under which she lives. He discharges the same role as don Diego de Miranda performs in Quijote. He pokes fun at no one and speaks the truth even when it is an unpleasant reality.

María first begins lying to her husband and then lies to others. This process deceit began because, as don Quijote says to don Diego in chapter 17, second part, sounds better to those that hear it" and for María it sounds better to say she is rich th she is poor. That is to say, she lies because of her vanity. Vanity and arrogance have caused her to separate more and more from her roots. It is therefore the moment for someone to show her again her proper place. At this time, we learn that her relatives, who represent the very roots she denies, arrive in the city. They first meet don Gil, Maria husband. Because of their ignorance these poor peasants are easy marks for the jests 0 the city residents, just as everyone laughed at don Quijote because he was crazy. In $\mathrm{fac}^{\mathrm{d}}$ there eas only one who did not laugh at Quijote - the discreet gentleman don Dief Miranda. We find the same thing in our sainete. Don Gil's friend suggests that he ridicu his in-laws; but don Gil, who is also a discreet gentleman, not only refuses to laugh them, he takes them to his home - as don Diego Miranda does with don Quijote. 
Here is where Ramón de la Cruz follows the Cervantine concept of discretion. For Cervantes the discreet man, as we have said, distinghishes between good and evil and takes the necessary measures to acheive the good. This is exactly what don Gil does. He knows that his wife changed following their marriage and that this change has not been a good one. She is, however, his wife and as he says, "what is done is done." It is his responsability now as a discreet husband to show María her mistakes. Thus when her family arrives he refuses to ridicule them as his friend suggests, but sees them rather as a means for the disillusionment of his wife.

When don Gil arrives at his home with his in-laws, María is entertaining friends who believe she has a prominent and wealthy family background. When the servant, therefore, announces that her mother is there to see her, María denies that such a woman could be who she claims to be and orders that she be thrown out of the house. As this moment her arrogance reaches its peak and her reason is at its lowest point. Her behavior is an outrage. She makes a tremendous blunder that she feels obligated to commit because she has been injudicious in lying about her backgound. It is time to impose discretion and to teach María a bitter lesson, putting things into their proper perspective. Her husband enters and reproaches her for denying the one who gave her life. Thus María falls from the pedestal that her indescretion has placed her upon. Her husband demonstrates that while she may feel that her roots are humble, she has no reason to feel humiliated by them. While no one can change his origins, he can hope to improve his future. We are now in the new society of the Enlightenment where the prestige of each individual is in his own acts, not those of his ancestors. As don Gil's friend says, "There is no shame in your birth if there is virtue to corret it."

Throughout this sainete we find a series of ten words, adjectives and nouns, that are also repeated numerous times in Don Quijote. They are the following: conceited, discreet, arrogant, vain, peace, harmony, blunder, virtue, disillusionment, and humble. These words form a decalog that gives us a moral precept. It is not by chance that six of these words come from don Gil since he represents the precept that teaches that discretion should dominate over arrogance. Looking at the decalog carefully, we see that the first word is conceited and the last is humble; they are two extremes and also the first and last words in our sainete. In the middle is discretion, through which one may acheive harmony. In this way, as in Don Quijote, the play maintains its closed structure since María, triumphing over her arrogance returns to the origins which she had denied. All occurs because her husband, with his discretion, enabled reason to triumph over passion, something which is necessary to achieve harmony.

\section{Department of Romance Languages \\ Wake Forest University - USA}

